\title{
The Supreme CourT's OverReaching PreEMPtion INTERPRETATION AND ITS CONSEQUENCES: GRANTING GENERIC DRUG MANUFACTURERS LEGAL IMMUNITY THROUGH "THE DUTY OF SAMENESS" IN MUTUAL PhaRMACEUTICAL Co. V. BARTLETT AND PLIVA V. MENSING
}

\author{
Tyler W. Olson*
}

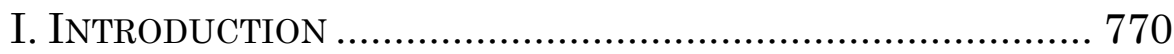

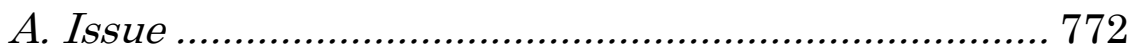

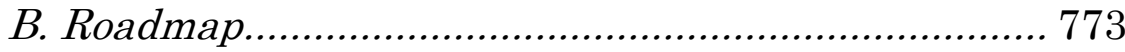

II. THE LAW AND REGULATORY RULES OF THE

PHARMACEUTICAL INDUSTRY ................................................. 774

A. Historical Background ............................................. 774

1. Patent Law ........................................................ 774

2. The Federal Food and Drugs Act, the Food Drug and

Cosmetics Act, and Hatch-Waxman Act .................. 777

B. Current Regulatory Laws Affecting Pharmaceutical

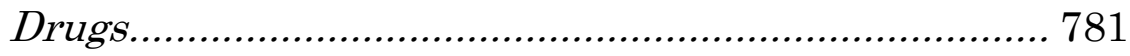

III. PREEMPTION DOCTRINE ANALYSIS .................................. 783

A. Preemption Doctrine............................................... 783

IV. CASE LAW, INDIANA STATUTORY Dissemination, AND

Recourse Available for Generic Drug Consumers .... 786

A. Wyeth, Pliva and Bartlett ..................................... 786

1. Wyeth - No State Tort Law Preemption from FDA's

Brand-Name Drug Regulations................................. 786

2. PLIVA - State Tort Law Preemption for Failure-to-

Warn Claims Against Generic Manufacturers ......... 788

3. Bartlett - State Tort Law Preemption for Design

Defect Claims Against Generic Manufacturers ........ 792

$B$. Indiana's Statutory Analysis and the Importance of

State Law................................................................ 795

C. Recourse Available to Generic Drug Consumers..... 800

1. Option One - Suing the Name Brand Manufacturer

* J.D. Candidate, 2015, Indiana University Robert H. McKinney School of Law; B.A., 2011, Ohio State University. 
2. Option Two - Suing the Generic Drug Manufacturer for Misbranding..................................................... 804 3. Option Three - Paying for Protection Through Brand

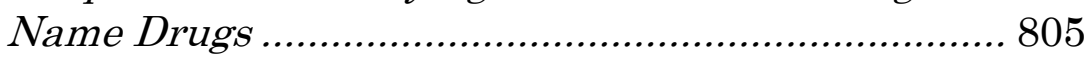
4. Option Four - Legislative Amendment ................. 806

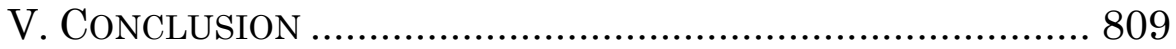

\section{INTRODUCTION}

National health expenditures in the United States are projected to exceed $\$ 3.093$ trillion in 2014. ${ }^{1}$ Prescription drug sales accounted for $8.9 \%$ of all national health expenditures in 2013. ${ }^{2}$ In 2014, these drug sales are projected to exceed $\$ 275.9$ billion of national health expenditures. ${ }^{3}$ The significant pharmaceutical drug sales are due, in large part, to the increasing commonality of treatment; in 2013, nearly seven in ten Americans took prescription drugs for treatment. ${ }^{4}$

Most pharmaceutical drugs brought to market are subject to patent protection. This limited protection provides incentives for drug development and research. However, following patent expiration it is common that brand-name drugs lose their market share to generic alternatives. ${ }^{5}$ These generic drugs provide more affordable

1 National Health Expenditure Projections 2012-2022, CENTER FOR MEDICARE \& MEDICAID SERVICES, http://www.cms.gov/ResearchStatistics-Data-and-Systems/Statistics-Trends-and-

Reports/NationalHealthExpendData/downloads/proj2012.pdf (last visited Mar. 16, 2015).

2 Id.

3 Id.

4 The most common prescription drugs taken were antibiotics, antiasthmas, painkillers, and antidepressants. Nearly 7 in 10 Americans Take Prescription Drugs, Mayo Clinic, Olmstead Medical Center Find, MAYO ClinIC (June 19, 2013), http://newsnetwork.mayoclinic.org/ discussion/nearly-7-in-10-americans-take-prescription-drugs-mayo-

clinic-olmsted-medical-center-find [hereinafter Nearly 7 in 10 Americans].

5 A "generic" drug in this Note refers to pharmaceutical equivalents of brand-name FDA approved drugs that exist post patent-expiration. For a full list of approved drugs with equivalence evaluations, see 
treatment options versus their brand-name counterparts. ${ }^{6}$ The savings of switching to generic drugs can be significant; for example, opting for generic drugs versus their brandname counterparts saved consumers an estimated $\$ 33$ billion in 2013. ${ }^{7}$ External forces are known to influence consumer choices for prescription filing 8 and an estimated $90 \%$ of prescription drugs written in 2007 were generic. ${ }^{9}$

The U.S. Constitution plays an important role of safeguarding fundamental interests of citizens. It establishes "a system of dual sovereignty between the States and the Federal Government." 10 As it relates to the pharmaceutical industry, this dual sovereignty allows the federal and state government the ability to enact protection laws for its citizens. Thus, the Constitution grants states the power to enact laws subject to the Supremacy Clause.. ${ }^{11}$ States have enacted tort laws that provide protection to its citizens. In the pharmaceutical industry, state tort laws "uncover unknown drug hazards and provide incentives for drug manufacturers to disclose safety risks promptly." 12

Orange Book, Approved Drug Products with Therapeutic Equivalence Evaluations, U.S. Food \& Drug Admin, http://www.accessdata.fda.gov/scripts/cder/ob/default.cfm (last visited Mar. 16, 2015).

6 Tod Cooperman, What You Need to Know About Generic Drugs (Apr. 8, 2013), http://www.doctoroz.com/videos/what-you-need-knowabout-generic-drugs.

7 Danielle L. Steele, The "Duty of Sameness" as a Shield--Generic Drug Manufacturers' Tort Liability and the Need for Label Independence After Pliva, Inc. v. Mensing, 43 Seton Hall L. Rev 441, 442-43 (2013) (citing Effects of Using Generic Drugs on Medicare's Prescription Drug Spending Cong. BudGet OfF. (Sept. 15, 2010), http://www.cbo.gov/sites/

default/files/cbofiles/ftpdocs/118xx/doc11838/09-15-

prescriptiondrugs.pdf).

8 See id. at 443 (stating that "[Private pharmaceutical benefit management companies] strategically manipulate pricing and coverage in order to influence patient behavior in prescription fulfillment." (Citations omitted)).

$9 \quad$ Id. at 442.

10 Gregory v. Ashcroft, 501 U.S. 452, 457 (1991).

11 U.S. ConsT. art. VI cl. 2.

12 Wyeth v. Levine, 555 U.S. 555, 579 (2009). 
These state tort laws also provide (sometimes limited) compensation to injured parties in an attempt to redress injuries. ${ }^{13}$ Additionally, these tort laws help to supplement gaps present in federal law, such as the lack of a private cause of action in the Food, Drug, and Cosmetic Act ("FDCA"). ${ }^{14}$

The long held constitutional right of permitting tort law causes of action for injured parties might no longer be available to generic drug consumers. Two recently decided Supreme Court cases have established precedent holding that while brand name drug manufacturers face liability for failure-to-warn and product liability claims, generic drug manufacturers will not face liability so long as it complies with the duty of sameness as defined in the FDCA. ${ }^{15}$ This precedent is preventing innocently injured consumers from being able to seek legal recourse against liable generic drug manufacturers. Addressing this issue or providing alternative legal courses remains paramount to protect consumer needs.

\section{A. Issue}

The two decisions issued by the Supreme Court will have debilitating effects on generic drug consumers in the U.S. marketplace. This precedent is likely to result in denying individuals who take generic drugs the ability to legally redress their injuries. This is significant because an estimated $80 \%$ of consumers opt for generic drug treatment. In PLIVA v. Mensing, the Court expanded the scope of the impossibility preemption. ${ }^{16}$ This expansion granted immunity to generic drug manufacturers from state law failure-to-warn claims. ${ }^{17}$ In PLIVA, two individuals that had developed tardive dyskinesia, a severe abnormal and

\footnotetext{
13 Id.

14 See Merrell Dow Pharm. Inc. v. Thompson, 478 U.S. 804 (1986) (reasoning that FDCA violations provide no federal cause of action).

1521 U.S.C. $\S \S 355(\mathrm{j})(2)(\mathrm{A})(\mathrm{ii})$-(iii) (2015).

16 PLIVA, Inc. v. Mensing, 131 S.Ct. 2567 (2011).

17 Id. at 2569.
} 
uncontrollable face movement disorder, ${ }^{18}$ were left without legal recourse. ${ }^{19}$ In Mutual Co. Pharmaceutical v. Bartlett, the Court unnecessarily expanded the reach of the preemption doctrine. ${ }^{20}$ The injured plaintiff purchased an affordable generic drug to treat her life threatening dermatologic disorder. However, as a result of the Court's preemption interpretation, she was left without legal recourse to address her debilitating injuries. ${ }^{21}$

These recent Supreme Court decisions raise the need for legislative action and/or statutory amendment. The Food and Drug Administration ("FDA") acts as a gatekeeper in "protect[ing] the public health by assuring the safety, efficacy, and security of human and veterinary drugs . . .."22 The FDA remains responsible "helping to speed innovations that make medicines more effective, safer, and more affordable ...."23 As a result of these two recent decisions, the FDA's responsibility is subject to this large gap that is preventing innocent generic drug consumers from seeking legal recourse to address their injuries. ${ }^{24}$

\section{B. Roadmap}

This Note discusses the ramifications of three recently decided Supreme Court cases dealing with federal preemption in the prescription drug marketplace: Wyeth $v$.

18 See Tardive dyskinesia, MeDLInEPLus, http://www.nlm.nih.gov/ medlineplus/ency/article/000685.htm (last visited Mar. 6, 2015) ("Tardive dyskinesia is a disorder that involves involuntary movements . . . , [especially of] the lower face. Tardive means delayed and dyskinesia means abnormal movement.")).

19 PLIVA, Inc., 131 S.Ct. at 2569.

20 Mut. Pharm. Co., Inc. v. Bartlett, 133 S.Ct. 2466, 2472 (2013) (The victim developed epidermal necrolysis, a skin eating bacteria).

21 Id.

22 About FDA: What We Do, U.S. Food \& DrUg ADMIN., http://www.fda.gov/aboutfda/whatwedo/ (last updated Aug. 5, 2014).

${ }^{23} I d$.

24 See Therapeutic Drug Use, Center for Disease Control \& PREVENTION, http://www.cdc.gov/nchs/fastats/drug-use-therapeutic.htm (last visited Mar. 16, 2015) (In 2007, 48.5\% of persons in the U.S. reported using least one prescription drug in the past thirty days). 
Levine, ${ }^{25}$ PLIVA v. Mensing, ${ }^{26}$ and Mutual Co. Pharm. v. Bartlett. ${ }^{27}$ To facilitate an understanding of the issue discussed, Section II explains the statutory history of both patent law and federal regulations applicable to generic and brand name pharmaceutical manufacturers. Section II will also discuss the procedural and regulatory thresholds that generic drug manufacturers are required to satisfy to bring its drugs to market. Section III will explore the preemption doctrine, delving into potential preemption scenarios that may arise as a legal argument. Section IV will analyze these three Supreme Court cases and it will apply this flawed precedent to Indiana by applying this precedent to previously decided Indiana cases. Finally, Section IV will explore possible options available to injured generic drug consumers.

\section{THE LAW AND REgULATORY RULES OF THE PHARMACEUTICAL INDUSTRY}

To understand the statutory structure of pharmaceutical law and market entry barriers pharmaceutical drugs face, it is important to understand the reasoning underlying the creation of the acts themselves. This section briefly explores U.S. patent law as it relates to generic and brand name drugs, it provides a brief history of acts relevant to the pharmaceutical industry, and it explores the barriers to entry applicable to brand name and generic drug manufacturers.

\section{A. Historical Background}

\section{Patent Law}

The original article of the Constitution provides the origin of patent protection. ${ }^{28}$ Patents play a central role in

25 Wyeth v. Levine, 555 U.S. 555 (2009).

26 PLIVA, Inc. v. Mensing, 131 S.Ct. 2567, 2570 (2011).

27 Mut. Pharm. Co. Inc., v. Bartlett, 133 S.Ct. 2466 (2013).

28 U.S. ConsT. art. I, § 8, cl. 8. 
the creation and development of pharmaceutical drugs. 29 By granting limited monopoly powers, these patents provide monetary incentives for companies to invest in researching and developing new drugs to bring to market. ${ }^{30}$ This limited monopoly is important in helping brand name drug manufacturers recoup the research and development costs of new drugs which may exceed $\$ 2.5$ billion. ${ }^{31}$ It is important to note, however, that this patent protection is with limits. For example, the Bolar exemption allows a generic drug manufacturer to start researching and testing for drug approval pre-patent expiration. ${ }^{32}$

Patent protection is authorized by Article 1, Section 8, Clause 8 of the U.S. Constitution, which states in part, "[t] promote the progress of Science and useful arts, by securing for limited Times . . . the exclusive Right to their respective Writings and Discoveries." 33 A patent is a property right

29 Patent FAQS, U.S. PAT. \& TRADEMARK OFF., http://www.uspto.gov/inventors/patents.jsp (last visited Mar. 16, 2015) (patents provide security on the idea for a limited duration).

3035 U.S.C. $\S 154(\mathrm{a})(2)$ (2015) (The patent term is 20 years from the filing date).

31 PR Tufts CSDD 2014 Cost Study, TuFTs CSDD, http://csdd.tufts.edu/news/complete_story/pr_tufts_csdd_2014_cost_stud y (last visited Mar. 30, 2015).

32 See Roche Prods., Inc. v. Bolar Pharm. Co., Inc., 733 F.2d 858 (Fed. Cir. 1984), superseded by statute as stated in Warner-Lambert Co. v. Apotex Corp. 316 F.3d 1348 (Fed. Cir. 2003) (The Bolar exemption also allows generic drug manufacturers to perform research and tests in preparation for regulatory approval prior to patent expiration, and this exemption immunizes the generic manufacturers against patent infringement suits. The rationale is for the Bolar exemption is to allow generic drug manufacturers the opportunity to conduct clinical trials on patented products before the products patent has expired). There are other exceptions and protections granted to generic drug manufacturers. For example, a paragraph 4 (often referred to as $\mathrm{P} 4$ ) certification is a form that generic firms can use to challenge current patents. If the brand-name manufacturer sues the generic filing P4 party, and it is determined that the patent is indeed invalid, the generic manufacturer is rewarded with a valuable 180-day marketing exclusivity period. The P4's origin traces back to the Hatch-Waxman Act.

33 U.S. ConsT. art. I, $\S 8$, cl. 8 (Congress shall have power "[t]o promote the Progress of Science and useful Arts, by securing for limited Times to Authors and Inventors the exclusive Right to their respective 
granted by the U.S. to an inventor "to exclude others from making, using, offering for sale, or selling the invention throughout the [U.S.] or importing the invention to the [U.S.]" for a limited time. ${ }^{34}$ For a patent to be held valid, there are many requirements. Generally, the patent must be novel, useful, and non-obvious to a person ordinarily skilled in the art. ${ }^{35}$ The patent subject matter must also be patentable ${ }^{36}$ and specified written materials must be part of every patent application. ${ }^{37}$

The original patent holder may be able to file for an extension on their monopoly powers. These extensions are subject to their own onerous requirements. Following the expiration of the patent term, whether or not an extension has been granted, generic drug manufacturers are able to

Writings and Discoveries.").

3435 U.S.C. $\S 154(\mathrm{a})(1)$ (2015).

35 Appendix L Consolidated Patent Laws, UsPTo.gov (last visited Mar. 16, 2015), http://www.uspto.gov/web/offices/pac/mpep/ consolidated_laws.pdf. See 35 U.S.C. $§ 102$ (2015) (novelty); see also Cornell Univ. L. Sch., Overview, Legal Information Institute, http://www.law.cornell.edu/wex/Patent (last visited Mar. 16, 2015) (hereinafter Overview) (generally, novelty requires that the invention wasn't known or used by others in the United States, or patented/described in print or publication in the United States or other country. To meet this, the invention must be new compared to prior art). See 35 U.S.C. § 101 (2015) (utility); see also Overview (generally, a patent does not have to have any economic value whatsoever, but it is required that the utility asserted in the application be credible, specific, and substantial). See 35 U.S.C. § 103 (2015) (non-obvious); see also Graham v. John Deere Co. of Kansas City, 383 U.S. 1 (1966) (establishing the test for non-obvious as whether the subject matter sought to be patented and prior art as such that the subject matter as a whole would've been obvious to a person having ordinary skill in the art at the time the invention was made).

$36 \quad 35$ U.S.C. $\S 103$ (2015). Generally, laws of nature, physical phenomena and abstract ideas are not patentable. The distinction between patentable and unpatentable subject matter is between products of nature, living or not, and human-made inventions.

3735 U.S.C. $§ 112$ (2015). For a more detailed discussion of specific written material requirements, see Patent, LEGAL INFO. INST., https://www.law.cornell.edu/wex/patent (last visited Mar. 30, 2015) ("Enablement is understood as encompassing three distinct requirements: the enablement requirement, the written description requirement, and the best mode requirement."). 
enter into the drug market through an abbreviated approval process. ${ }^{38}$

\section{The Federal Food and Drugs Act, the Food Drug and} Cosmetics Act, and Hatch-Waxman Act

The origin of regulations for health consumer goods was created in 1906. The 1906 passage of the Pure Food and Drugs Act ("PFDA") began the FDA's origin as a federal consumer protection agency. ${ }^{39}$ The FDA's responsibilities have been amended since the initial passage of the PFDA and the FDA's current responsibilities in the pharmaceutical industry involve overseeing drug approval and post approval safety. ${ }^{40}$ The FDA acts as a gatekeeper and the agency plays an important role in pharmaceutical regulation. ${ }^{41}$

Prior to the PFDA, the "[u] se of chemical preservatives . . . was virtually uncontrolled." 42 Manufacturers were not subject to any approval process and could freely enter the market and sell drugs. The PFDA passage ${ }^{43}$ helped address

38 See infra note 40. See also How Increased Competition from Generic Drugs has Affected Prices and Returns in the Pharmaceutical Industry, CONG. BUDGET OFF., http://www.cbo.gov/publication/ 10938?index $=655$ (last visited Mar. 16, 2015) (hereinafter How Increased Competition has Affected Prices and Returns).

39 About FDA: When and Why was FDA Formed?, U.S. Food \& DRUG ADMIN., http://www.fda.gov/AboutFDA/Transparency/ Basics/ucm214403.htm (last visited Mar. 16, 2015).

40 About FDA: Office of Medical Products and Tobacco, U.S. FooD \& DRUG ADMIN., http://www.fda.gov/AboutFDA/CentersOffices/ OfficeofMedicalProductsandTobacco/ucm20025997.htm (last visited Mar. 16, 2015).

41 Steele, supra note 7 at 469 (The United State Government and Accountability Office ("GAO") has raised concerns over the FDA's "management of safety issues for drugs approved for marketing." The FDA staff has "expressed concern about their ability to meet a growing post market workload, with some maintaining that their premarket responsibilities are considered a higher priority." (Citations omitted)).

42 Wallace F. Janssen, The Story of the Laws Behind the Labels, U.S. FOOD \& DRUG ADMIN. (June 1981), http://www.fda.gov/AboutFDA /WhatWeDo/History/Overviews/ucm056044.htm.

4334 Stat. 768 (1906) (repealed in 1938 by 21 U.S.C. $\S 329(\mathrm{a})$ ). 
the uncontrolled industry by prohibiting the manufacturing or interstate shipment of adulterated or misbranded drugs. The PFDA also helped by supplementing consumer protections already provided by state regulation and common law liability. ${ }^{44}$ After expressing concern about unsafe drugs and fraudulent marketing, Congress enacted the Federal Food, Drug, and Cosmetic Act ("FDCA"). 45 This required the premarket approval of new drugs by requiring every drug manufacturer to submit a new drug application ("NDA"), including all reports and investigations, to the FDA for review. 46

Congress amended the FDCA in 1962. ${ }^{47}$ This amendment shifted the burden of proof from the FDA to the manufacturer to gain drug approval. This amendment also requires manufacturers to prove a drug's effectiveness by introducing "substantial evidence ... that the drug will have the effect it purports or is represented to have under the conditions of use prescribed, recommended, or suggested in the proposed labeling." 48 Furthermore, this amendment added a clause stating that state law would be invalidated only upon a "direct and positive conflict' with the FDCA. 49 This clause remains important to current preemption analysis and it will be analyzed in depth below.

Congress sought to facilitate the quicker approval of generic drugs into the marketplace. To streamline the generic drug approval process, Congress enacted the Drug Price Competition and Patent Term Restoration Act in 1984 (hereinafter the "Hatch-Waxman Act"). ${ }^{50}$ Prior to enacting the Hatch-Waxman Act, generic drug manufacturers were required to undertake the same approval as brand name

\footnotetext{
44 Id.

45 Pub. L. No. 75-717, 52 Stat. 1040 (1938).

46 Id.

47 Pub.L. No. 87-781, 76 Stat. 780 (1962) (codified as amended in scattered sections of 21 U.S.C.).

48 Id.

49 Wyeth v. Levine, 555 U.S. 555, 567 (2009) (citations omitted)(emphasis added).

50 Drug Price Competition and Patent Term Restoration Act, Pub. L. No. 98-417, 98 Stat. 1585 (codified as amended in scattered sections of 21 U.S.C.).
} 
drug manufacturers. This demanding approval process deterred the drug approval applications by generic drug manufacturers because the cost of such approvals would rarely be outweighed by the profit potential. This act (and subsequent amendments) created the Abbreviated New Drug Application ("ANDA"), a rule that expedites generic drug approval by permitting reliance on brand name drug data. ${ }^{51}$ It is important to note that the Hatch-Waxman Act focused largely on small molecule drugs ("SMD's") versus biologics. These SMD's are different in that they are often small (sometimes a single molecule), they are produced by chemical synthesis and they are often stable, whereas biologics are large (molecule mixtures), complex, produced by living cell cultures and difficult to control. ${ }^{52}$

While generic drug approval is available, such analysis is not the subject of this Note. Generic drug approval is available for biologics. ${ }^{53}$ To provide a brief summary, the Biologics Price Competition and Innovation Act (which is included in the Patient Protection and Affordable Care Act of 2009) helped address the availability of biologics by "allow[ing] the submission of a biological license application (BLA) for a biosimilar or interchangeable biological." 54 This regulatory scheme mirrors the ANDA process by

51 See generally 21 C.F.R. $\$ 314$ et seq. (2015).

52 Small Molecule Drugs Versus Biological Drugs, Generics \& BIOSIMILARS INITIATIVE (June 29, 2012), http://www.gabionline.net/Biosimilars/Research/Small-molecule-versusbiological-drugs.

53 Biologics is a large and complex issue that has been the topic of several articles, commentaries, and studies which analyze the Biologics act, the similarities this act has to the ANDA process, and the complexities of biologics. See Brenda F. Gehani, The Biologics Act: Hopes for Access to Generic Biologics May Instead be a Catalyst for New Innovation, 20 AnNals Health L. 170 (2011). See also Parker Tresmer, Interests in the Balance FDA Regulations Under the Biologics Price Competition and Innovation Act, 16 ULCA J. L. \& TECH. 1 (2012); Sara Margolis, Destined for Failure? An Analysis of the Biologics Price Competition and Innovation Act of 2009, 2013 ColuM. BUS. L. REV. 209 (2013).

54 Biologics Price Competition and Innovation Act, DemocratiC POL'Y \& COMM. CENTER, http://www.dpc.senate.gov/healthreformbill/ healthbill70.pdf (last visited Mar. 18, 2015). 
"[p]ermit[ting] the FDA, following a public process, to issue guidance related to the approval of biosimilar and interchangeable biological products." 55

When the Hatch-Waxman Act was enacted in 1984, generic drugs accounted for $19 \%$ of all drug sales in the United States. ${ }^{56}$ The Hatch-Waxman Act's ANDA process allowed generic drug manufacturers to enter the marketplace without the restraints new brand name drug manufacturers face. As such, it was not long before generic drugs comprised the majority of the market. Generic drug approval costs dropped substantially due to the ANDA process. ${ }^{57}$ As a result, the generic drug approval applications and sales steadily increased. Currently, 90\% of drug prescriptions are filled with generic counterparts. ${ }^{58}$

The most recent FDCA amendment relating to pharmaceuticals was passed in 2007 when Congress "adopted a rule of construction to make it clear that manufacturers remain responsible for updating their labels." 59 The Food and Drug Administration Amendments Act ("FDAAA") increased the burden placed on drug manufacturers. ${ }^{60}$ Importantly, the FDA granted statutory authority under the FDAAA (and other parts of the FDCA) allowing it to require drug manufacturers to change drug labels based upon information discovered after a drug has been approved for market. ${ }^{61}$ That is because manufacturers

55 Id. (Noting that this act "[a]wards brand manufacturers and innovators 12 years of data exclusivity from the approval date of the product." This will essentially expand the viable monopoly sale time of the brand-name biologic by preventing generic companies from relying on their previous research).

56 How Increased Competition has Affected Prices and Returns, supra note 35.

57 Steele, supra note 7 at 451 (Noting that "the average cost of bringing a generic to market is under $\$ 2$ million, less than a quarter of the average costs associated with novel drugs.").

58 Steele, supra note 7 at 442.

59 Wyeth, 555 U.S. 555, 568 (2009) (citations omitted) (emphasis added).

60 Pub. L. No. 110-85. 121 Stat. 83 (2007).

61 Food and Drug Administration Amendments Act of 2007, Pub. L. No. 110-85, 121 Stat. 823 (codified as amended in scattered sections of 21 U.S.C.). 
who have greater "access to information about their drugs" than the FDA retain the ultimate responsibility for the safety of their products. ${ }^{62}$ Therefore, this requirement would place the burden on drug manufacturers and it provides incentives for manufacturers to provide wholly accurate and timely updates because it is their potential liability for failing to do so.

\section{B. Current Regulatory Laws Affecting Pharmaceutical Drugs}

Under current law, if a generic drug is identical to an FDA approved brand-name drug in several aspects, it may be approved without the same onerous requirements of brand-name drugs. ${ }^{63}$ First, the proposed generic drug must be chemically equivalent to the approved brand-name drug. 64 This requires the generic drug to have the same "active ingredient" or "active ingredients," "route of administration," "dosage form," and "strength" as the approved brand-name drug. ${ }^{65}$ Second, the generic drug must be "bioequivalent" to the approved brand-name drug. ${ }^{66}$ To be considered bioequivalent, a generic drug has to have the same "rate and extent of absorption ..." as its brandname counterpart. ${ }^{67}$ Third, generic drug manufacturers must show that the "labeling proposed for the new drug is the same as the labeling approved for the listed drug . . .."68 This labeling requirement has been argued (and interpreted) as meaning generic drug manufacturers are not able to unilaterally change their labels to strengthen warnings. 69

The FDA approves generic drugs only if they are determined "safe for use" under "conditions of use

\footnotetext{
62 Wyeth, 555 U.S. at 578-79.

63 Bartlett, 133 S.Ct. at 2471.

6421 U.S.C. $\S 355(\mathrm{j})(2)(\mathrm{A})(\mathrm{ii})(2015)$.

65 Id. $\S \S 355(\mathrm{j})(2)(\mathrm{A})(\mathrm{ii})-(\mathrm{iii})(2015)$.

$66 \quad I d . \S 355(\mathrm{j})(2)(\mathrm{A})(\mathrm{iv})$.

$67 \quad I d . \S 355(\mathrm{j})(8)(\mathrm{B})(\mathrm{i})$.

$68 \quad I d . \S 355(\mathrm{j})(2)(\mathrm{A})(\mathrm{v})$.

69 PLIVA, Inc. v. Mensing, 131 S.Ct. 2575 (2011).
} 
prescribed, recommended, or suggested in the proposed label thereof." 70 The risk of harm must be outweighed by the "probable therapeutic benefits . . .."71 Once a generic drug is approved, a manufacturer is prohibited from making any major changes to the quantitative or qualitative formulation of the drug, including but not limited to its active ingredients or specifications included in the approved application. ${ }^{72}$ Therefore, generic drugs are required to have the same dosage form, strength, active ingredients, and route of administration as their brand-name counterpart. ${ }^{73}$

In an attempt to continually promote drug efficacy and safety, both ANDA's and NDA's are required by federal regulations to comply with reporting and monitoring requirements regarding drug safety. ${ }^{74}$ Failure to comply with these regulations by establishing and maintaining records may result in the FDA "withdraw[ing] approval of the application and, thus, prohibit[ing] continued marketing of the drug product that is the subject of the application."75 Furthermore, to facilitate consumer safety, drug manufacturers may "add or strengthen a contraindication, warning, precaution, or adverse reaction ..." without prior approval so long as they notify the FDA thirty days prior to drug distribution. ${ }^{76}$ It would appear that the previous responsibility would hold generic drug manufacturers liable for failing to update their labels. However, as discussed below, the duty of sameness absolves generic drug manufacturers of liability.

7021 U.S.C. $\S 355(\mathrm{~d})(2015)$.

71 FDA v. Brown \& Williamson Tobacco Corp., 529 U.S. 120, 140 (2000).

7221 C.F.R. $\S 314.70(\mathrm{~b})(2)(\mathrm{i})(2015)$.

7321 U.S.C. $\S 355(\mathrm{j})(2015)$.

7421 C.F.R. § 314.98(a) ("[E]ach applicant having an approved abbreviated new drug application . . . that is effective shall comply with the requirements of $\$ 314.80$ regarding the reporting and recordkeeping of adverse drug experiences."). See 21 C.F.R. $\$ 314.80$ for requirements.

7521 C.F.R. $\S 314.80(j)$ ("Withdrawal of approval. If an applicant fails to establish and maintain records and make reports required under this section, FDA may withdraw approval of the application and, thus, prohibit continued marketing of the drug product that is the subject of the application.").

7621 C.F.R. § 314.70(c)(6)(iii) (2015). 


\section{PREEMPTION DoCTRINE ANALYSIS}

The preemption doctrine plays an important role in understanding the shortcomings of these two recently decided Supreme Court cases, PLIVA and Bartlett. To facilitate the understanding of this doctrine, this section will explore the origin of the preemption doctrine while providing scenarios where the doctrine may be applicable.

\section{A. Preemption Doctrine}

The preemption doctrine originated through judicial interpretation from the Supremacy Clause. The Supreme Court first relied on the Supremacy Clause in the 1796 case Ware v. Hylton. ${ }^{77}$ The Supremacy Clause states, in part, that the "Constitution, and the Laws of the United States. . . shall be the supreme Law of the Land . . ."78 Therefore, the Supremacy Clause has federal law preempt (or reign supreme) over state law when two laws conflict. In circumstances where the Supremacy Clause is applicable, the state law that conflicts with the federal law is generally "without effect."79

Federal preemption is often divided into two categories: express preemption and implied preemption. 80 Express preemption exists when there is an explicit statutory provision stating that federal law will supersede law. 81 Therefore, when an explicit statutory provision exists stating federal law supersedes all other laws, the general inquiry is whether the state law falls with the scope of the federal law. ${ }^{82}$ To illustrate, the Employee Retirement

77 Ware v. Hylton, 3 U.S. 199 (1796) (invalidating a Virginia law providing for confiscation of debts owed to a British subject under the Supremacy Clause).

78 U.S. ConsT. art. VI, cl. 2 (emphasis added).

79 Maryland v. Louisana, 451 U.S. 725, 746 (1981).

80 Jennifer S. Hendricks, Preemption of Common Law Claims and the Prospects for FIFRA: Justice Stevens Puts the Genie Back in the Bottle, 15 Duke ENVTL., L. \& Pol’Y F. 65, 69 (2004).

81 Id.

82 Id. at 70. 
Income Security Act (often referred to as "ERISA") section 514 expressly preempts all state laws "relating to" employer-sponsored health plans. ${ }^{83}$

Implied preemption exists in three scenarios. First, implied preemption may exist where state law creates an obstacle for compliance with federal law. ${ }^{84}$ For example, in Hines v. Davidowitz the Court held that Pennsylvania's alien registration system stood "as an obstacle to the accomplishment and execution of the full purposes and objectives of Congress['] [Alien Registration Act.]". 85 Pennsylvania's alien registration was preempted by Congress' Alien Registration Act and was held invalid. Second, implied preemption may exist where Congressional law occupies an entire field so as to create an "inference of federal exclusivity." 86 For example, in Gade v. National Solid Wastes Management Association the Court determined that an Illinois provision applicable to licensing workers who handled hazardous waste materials was preempted by federal Occupational Safety and Health Administration regulations because such regulations occupied the whole field of handling hazardous waste material. 87

Third, implied preemption may occur where it is impossible for one to comply with both federal and state law due to direct conflict between federal and state law. ${ }^{88}$ For example, if a state law explicitly permits something federal law forbids, a direct conflict would likely exist and state law would probably be preempted. ${ }^{89}$ It is important to note that raising impossibility preemption is a demanding defense. ${ }^{90}$ The main inquiry is whether the private party could

8329 U.S.C. $§ 1144($ a) (2015). For a more detailed ERISA analysis, see ERISA Preemption Primer, NAT'L ACAD. For STATe Health Pol'y, http://nashp.org/sites/default/files/ERISA_Primer.pdf

?q=Files/ERISA_Primer.pdf (last visited Mar. 20, 2015).

84 Hendricks, supra note 80 at 70.

85 Hines v. Davidowitz, 312 U.S. 52, 68 (1941).

86 Hendricks, supra note 80 at 70.

87 Gade v. Nat'l Solid Wastes Mgmt. Ass'n., 505 U.S. 88 (1992).

88 Hendricks, supra note 80 at 70.

89 Id.

90 Wyeth v. Levine, 555 U.S. 555, 573 (2009). 
independently do under federal law what state law requires of it. ${ }^{91}$ When state and federal law impose irreconcilable conflicting affirmative requirements, an inquiry into congressional design is unnecessary because Congress' intent to have federal law displace the conflicting state law "is inescapable." 92 Because there is a presumption against finding preemption, it is much less common for courts to find preemption than to not. 93

Congress plays an important role of being the "ultimate touchstone' in every pre-emption case." 94 Therefore, courts should defer to Congress' intent in deciding whether preemption should apply. Unless it was the clear intent and purpose of Congress to have a federal act supersede state law, police powers of the state should not be held preempted. 95 Furthermore, when Congress has legislated in a field traditionally occupied by the States"[t]hat assumption . . . applies with particular force . . . ."96 Therefore, absent direct conflict, courts cannot assume Congress intended for preemption to exist. 97 A detailed inquiry into congressional intent should be made, and where a statute contains no explicit preemption command, courts may infer that the administrative agency has a degree of leeway to determine the extent to which "statutes, rules, regulations or other administrative actions have preemptive effect." 98 These fundamental principles were

91 Id.

92 See Mut. Pharm. Co.,133 S.Ct. at 2473 (citing Florida Lime \& Avocado Growers, Inc. v. Paul, 373 U.S. 132, 142-43 ("A holding of federal exclusion of state law is inescapable and requires no inquiry into congressional design where compliance with both federal and state regulations is a physical impossibility for one engaged in interstate commerce.")).

93 Kerry Abrams, Plenary Power Preemption, 99 VA. L. REV. 601, 608 (2013).

94 Medtronic, Inc. v. Lohr, 518 U.S. 470, 485 (1996).

95 Id. (citing Altria Group, Inc. v. Good, 555 U.S. 70, 77 (2008)).

96 Id. (citing Altria Group, Inc. v. Good, 555 U.S. 70, 77 (2008)).

97 Id. at 2486.

98 Id. at 2481 (Breyer, J., dissenting) (citing Smiley v. Citibank (South Dakota), 517 U.S. 735, 739-41 (1996)). 
applied to the FDCA in the first of three fundamental cases, Wyeth v. Levine. ${ }^{99}$

\section{CASE LAW, INDIANA STATUTORY DisSEMINATION, AND RECOURSE AVAILABLE FOR GENERIC DRUG CONSUMERS}

This section will explore the three recently decide Supreme Cases relevant to the preemption inquiry. This section will then continue by exploring Indiana law as it relates to this precedent and it will demonstrate how previously decided cases would likely result in unjust and inequitable decisions following the Court's precedent. Finally, this section will explore alternative options available for generic drug consumers to protect themselves.

\section{A. Wyeth, Pliva and Bartlett}

\section{Wyeth - No State Tort Law Preemption from FDA's Brand-Name Drug Regulations}

The first of the three Supreme Court cases involved a plaintiff that brought suit against a brand-name drug manufacturer on a failure-to-warn claim. 100 In Wyeth $v$. Levine, respondent Diana Levine suffered injuries from an IV-push injection of Phenergan. ${ }^{101}$ As a result from such injuries, Ms. Levine was required to have her right hand and forearm amputated. ${ }^{102}$ Ms. Levine suffered substantial medical expenses and the loss of her livelihood as professional musician. ${ }^{103}$ In their decision, the jury found Wyeth negligent and concluded that Phenergan was a defective product that had inadequate warnings and instructions. ${ }^{104}$ Specifically, the instructions had failed to "instruct clinicians to use the IV-drip method of intravenous

\footnotetext{
99 Wyeth v. Levine, 555 U.S. 555, 581 (2009).

100 Id. at 560 .

101 Id.

102 Id. at 559.

103 Id.

104 Id. at 562.
} 
administration instead of the higher risk IV-push method" that was used on Ms. Levine. ${ }^{105}$

The drug manufacturer claimed impossibility preemption in the appeal. ${ }^{106}$ The manufacturer argued it was impossible to comply with the state-law duty to modify Phenergan's label because federal law prohibited the unilateral change of a drugs label.107 In dispensing with this argument, the Court reasoned the manufacturer failed to demonstrate it was impossible to comply with both federal and state law. 108 Under the Court's analysis, the Changes Being Effected ("CBE") regulation allowed manufacturers to supplement and change their label. 109 This "permitted Wyeth to unilaterally strengthen its warning, and the mere fact that the FDA approved Phenergan's label [did] not establish that it would have prohibited such a change." 110

In the concurrence, Justice Breyer stated the Court had "no occasion in this case to consider the pre-emptive effect of a specific agency regulation being the force of law." $111 \mathrm{He}$ continued by reasoning that federal statutes and regulations neither protected the manufacturer from the risk of state-law liability nor prohibited the stronger warning label required by the state Court's judgment. ${ }^{112}$ Comparatively, in another concurrence, Justice Thomas concluded that with no "direct conflict" between the federal and state law, the state-law judgment was not preempted. 113 The majority decision was consistent with the long-established presumption against finding

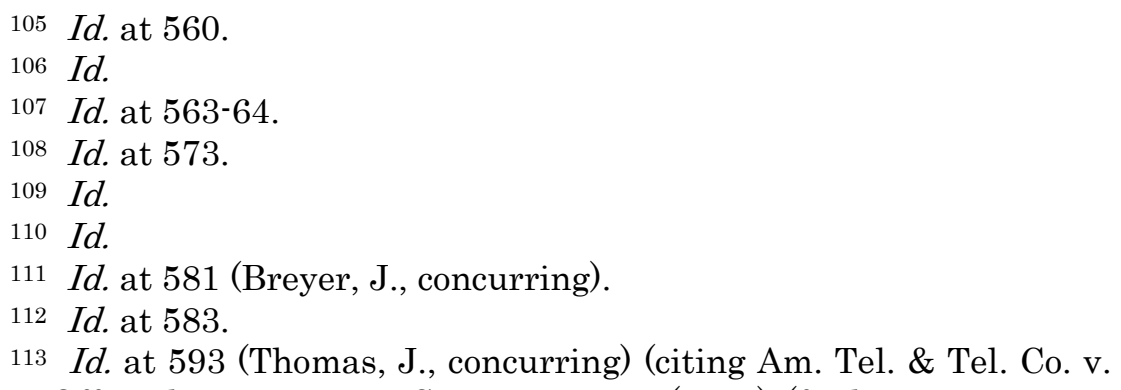
Cent. Off. Tel., Inc., 524 U.S. 214, 221-26 (1998) (finding preemption where federal law forbade common carriers from extending communications privileges requested by state-law claims)). 
preemption. This presumption would be discarded less than two years later in a subsequent Supreme Court decision.

2. PLIVA - State Tort Law Preemption for Failure-toWarn Claims Against Generic Manufacturers

The Court in Pliva v. Mensing went directly against the reasoning and holding in Wyeth. In Pliva v. Mensing, the Court expanded the scope of the impossibility preemption, which resulted in granting immunity to generic drug manufacturers in state-law failure-to-warn claims. ${ }^{114}$ Two separate suits were consolidated into one lawsuit and the drug at issue was a generic equivalent, not the brand-name drug. 115 Both plaintiffs had been prescribed metoclopramide - a generic version of the drug Reglan - to treat their digestive tract problems. ${ }^{116}$ After taking the generic drug for several years, both plaintiffs developed tardive dyskinesia, a disorder of involuntary bodily movements. ${ }^{117}$ The plaintiffs argued the generic drug manufacturer was liable for failing to provide adequate warning labels, as required by state law. ${ }^{118}$ The plaintiffs also argued that the CBE process explicitly permitted manufacturers to change their labels when additional information is available. ${ }^{119}$

The CBE process permits drug manufacturers to "add or strengthen" its labels. ${ }^{120}$ The FDA told the Court that label strengthening by a generic drug manufacturer is permissible only if the generic drug manufacturer sought to change the label to match that of an updated brand-name drug. ${ }^{121}$ The FDA continued by arguing its interpretation was not determined to be "plainly erroneous or inconsistent with the regulation." 122 Furthermore, the FDA opined for

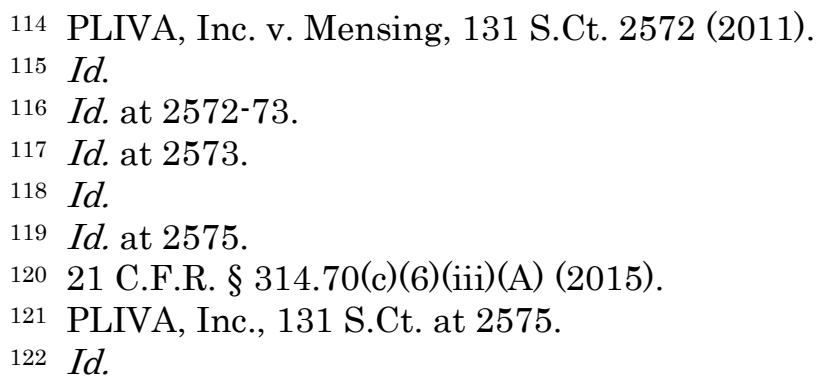


the Court to hold the manufacturer to the "duty of sameness" standard and to not permit the unilateral label change under the CBE process. ${ }^{123}$

The generic drug manufacturer argued that FDA regulations and federal statute preempted state law tort claims because the federal "duty of sameness" required the same labeling for their generic drug metoclopramide ${ }^{124}$ as the non-generic drug Reglan had. ${ }^{125}$ The Court agreed and found that impossibility preemption was present because the state law required the generic manufacturer to change the drug label in a way to make it reasonably safe while the FDA regulation explicitly prevented generic drug manufacturers from independently changing their generic drug safety labels. ${ }^{126}$ Therefore, as pointed out in Justice Sotomayor's dissent, the majority assumed that generic drug manufacturers "read the FDA regulation to require them only to ensure that their labels match the brand-name labels." 127

Under current law, a drug's "labeling must be revised to include a warning about a clinically significant hazard as soon as there is reasonable evidence of a causal association with a drug; a causal relationship need not have been definitely established." 128 However, the court did not address the issue of whether the generic drug manufacturer had a duty to request a strengthened label from the FDA; "[b]ecause [the Court] ultimately [found] preemption even assuming such a duty [to request a strengthened label] existed, [the Court did] not resolve the matter" of whether there was a duty on the generic drug manufacturer to request a strengthened label. ${ }^{129}$ Thus, under the majorities' flawed reasoning, "[h]ad [petitioners] taken Reglan, the brand-name drug prescribed by their doctors, Wyeth would control and their lawsuits would not be pre-empted. But

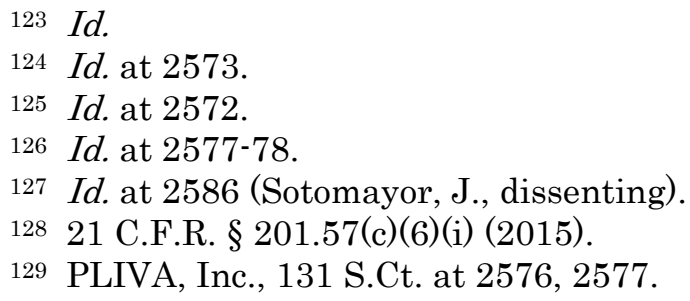


because [they were prescribed with] metoclopramide instead, federal law preempts these lawsuits."130

Generic drug manufacturers should not be permitted to "sustain their burden of showing impossibility if they have not even attempted to employ that mechanism." 131 A generic drug manufacturer should have the burden to propose label changes to the FDA, and in the event such proposal is denied, then it would be possible for impossibility preemption to exist. ${ }^{132}$ As such, generic drug manufacturers should not be granted preemption protection without even attempting to propose change. As a result of the Court's decision in Pliva, generic drug consumers have no legal recourse against generic drug manufacturers who fail to update their labels. Consequently, generic drug manufacturers no longer will "monitor and disclose safety risks" they find as they will be able to rely solely on brandname manufacturer label changes or being immune through the preemption doctrine. ${ }^{133}$ Currently $90 \%$ of consumers opt for generic drug alternatives, and under this dangerous precedent, many consumers may not have modes of relief for injuries against generic drug manufacturers. ${ }^{134}$

It was not impossible for the generic drug manufacturer to comply with federal and state law in Pliva. The manufacturer could have approached the FDA and the agency may well have agreed that a change to the label was necessary. ${ }^{135}$ However, the Court created a new law: "[t]he question for 'impossibility' is whether the private party could independently do under federal law what state law

\footnotetext{
130 Id. at 2581.

131 Id. at 2589 (Sotomayor, J., dissenting).

132 Id. at 2588.

133 Unequal Justice: Pliva v. Mensing, Alliance fOR Just., http://www.afj.org/multimedia/first-monday-films/unequal-justice-plivav-mensing (last visited Mar. 20, 2015).

134 Brian Wolfman \& Anne King, Mutual Pharmaceutical Co. v. Bartlett and Its Implications, BUREAU OF NAT'L AFF., http://about.bloomberglaw.com/practitioner-contributions/mutualpharmaceutical-co-v-bartlett-and-its-implications/ (last visited Mar. 20, 2015).

135 PLIVA, Inc., 131 S.Ct. at 2587 (Sotomayor, J., dissenting).
} 
requires of it." 136 This interpretation flew against the longstanding presumption against preemption such that courts required a "strong" showing of conflict "to overcome the presumption that state and local regulation can constitutionally coexist with federal regulation." 137

The Pliva decision indirectly gives physicians the authority to tell patients that while it may be cheaper to use generic drugs, they may have no legal protections if the generic drug injures them. Notably, "the dispensing of generic drugs on 'brand-written' prescriptions rather than generically written prescriptions [have] become the chief source of generic drug sales through pharmacies." 138 Furthermore, every state has a law governing generic drug substitution and fourteen states mandate generic substitution if "brand only" isn't indicated by the prescribing physician. ${ }^{139}$ The danger of these substitution laws is that a patient may unknowingly be given a generic drug, which further exacerbates the likelihood of a consumer taking a drug in which they have no legal recourse against the manufacturer. ${ }^{140}$ Pharmacists also have financial incentives to dispense generics because it increases profit margins. ${ }^{141}$

Balancing affordability with safety is an inequitable decision innocent consumers should not be faced with. In Pliva, the majority did not show a "clear and manifest purpose of Congress" because Congress did not expressly preempt label changing. ${ }^{142}$ Congress explicitly enacted an express preemption provision for medical devices in 1976 and it declined to do so for pharmaceuticals. ${ }^{143}$ It would

136 Id. at 2579.

137 Id. at 2591 (Sotomayor, J., dissenting) (citing Hillsborough Cnty. v. Automated Medical Laboratories, Inc., 471 U.S. 707 (1985)).

138 Steele, supra note 7 at 461.

139 Expanding the Use of Generic Drugs, U.S. DeP'T OF Health \& HUMAN SERVS., (Dec. http://aspe.hhs.gov/sp/reports/2010/GenericDrugs/ib.pdf.

140 Id.

141 Steele, supra note 7 at 462.

142 Wyeth v. Levine, 555 U.S. 555, 565 (2009).

14321 U.S.C. $\$ 360 \mathrm{k}(\mathrm{a})(2015)$. 
seem more likely than not that Congress did not intend for prescription drugs to be governed by preemption provisions. The holding goes against the holding in Wyeth and the commonly held notion to FDCA and FDA regulations that the manufacturer bears responsibility for the content of its label "at all times." 144 After all, the Court itself agreed that holding a brand-name manufacturer and not a generic drug manufacturer liable "makes little sense." 145

\section{Bartlett - State Tort Law Preemption for Design Defect Claims Against Generic Manufacturers}

Two years following the Pliva decision the Court unnecessarily expanded the already overreaching application of the preemption doctrine. ${ }^{146}$ In Mutual Pharmaceutical Co. v. Bartlett Karen Bartlett, the plaintiff, was prescribed Sulindac - a generic version of the drug Clinoril - for her shoulder pain. ${ }^{147}$ As a result of taking Sulindac, Ms. Bartlett developed toxic epidermal necrolysis - a skin condition that causes ones skin to peel in sheets leaving large areas of her skin exposed. ${ }^{148}$ When Ms. Bartlett was prescribed Sulindac the drug did not warn of the risk of developing toxic epidermal necrolysis. ${ }^{149}$ Soon

144 Wyeth, 555 U.S. at 571.

145 PLIVA, Inc. v. Mensing, 131 S.Ct. 2581 (2011).

146 Mut. Pharm. Co., Inc. v. Bartlett, 133 S.Ct 2466 (2013).

147 Id. at 2472. Sulindac is a "non-steroidal, anti-inflammatory indene derivative designated chemically . . . Clinoril gained FDA approval in 1978 and clinical trials at that time revealed negative side effects as "relatively mild." See Clinoril, RXLisT, http://www.rxlist.com/clinoril-drug.htm (last visited Mar. 21, 2015). See also Brief for Respondent, Mut. Pharm. Co., Inc. v. Bartlett, 133 S.Ct 2466 (2013) (No. 12-142), 2013 WL 602909, at *5 (noting that Mutual Pharmaceutical's ANDA was approved in 1991).

148 Mut. Pharm. Co., 133 S.Ct. at 2472. See also Toxic Epidermal Necrolysis, JOHNS HOPKINS MED., http://www.hopkinsmedicine.org/ healthlibrary/conditions/dermatology/toxic_epidermal_necrolysis_85,P0 0321/ (last visited Mar. 21, 2015) (noting that the disease progresses fast and treatment involves hospitalization in a burn unit and includes antibiotics, protective bandages, and intravenous immunoglobulin G (used to prevent further immune system damage)).

149 Mut. Pharm. Co., 133 S.Ct. at 2472. 
after Ms. Bartlett filed suit in New Hampshire State Court, the case was removed to federal court and a jury found Mutual Pharmaceutical liable under a design-defect claim. ${ }^{150}$ The First Circuit affirmed the decision of the jury, finding no preemption. ${ }^{151}$ However, Mutual Pharmaceutical appealed the decision and the Supreme Court held designdefect claims turning on the adequacy of a drugs warning are preempted. ${ }^{152}$

New Hampshire courts employ a "risk-utility approach" in the design-defect analysis. ${ }^{153}$ New Hampshire courts ask whether "magnitude of the danger outweighs the utility of the product." 154 Generally, New Hampshire courts consider three main factors, although such are non-exhaustive, which include: "[1] the usefulness and desirability of the product to the public as a whole, [2] whether the risk of danger could have been reduced without significantly affecting either the product's effectiveness or manufacturing cost, and [3] the presence and efficacy of a warning to avoid an unreasonable risk of harm from hidden dangers or from foreseeable uses." 155

The Supreme Court reasoned in their decision that increasing Sulindac's "usefulness" or reducing its "risk of danger" was not possible because the FDCA explicitly requires generic drugs to have the same active ingredients 156 and because the simple composition of Sulindac prevented it from being redesigned. ${ }^{157}$ The Court further reasoned that strengthening Sulindac's warning label was Mutual Pharmaceutical's only way to minimize its "risk-utility" profile. ${ }^{158}$ Therefore, because Mutual Pharmaceutical was not permitted to strengthen their label,

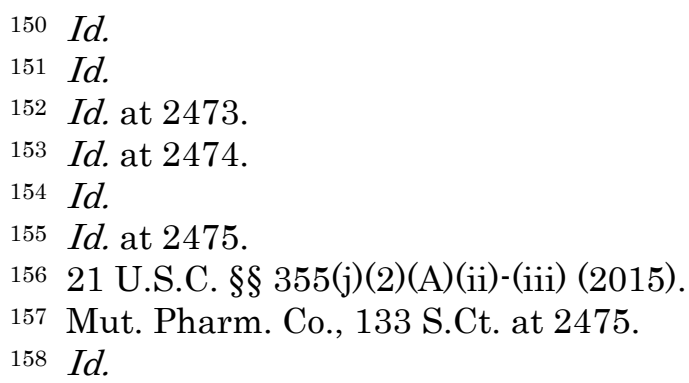


the Court concluded that federal law as discussed under Pliva prevented a unilateral change to Sulindac's label. ${ }^{159}$

The Court's holding presupposes that drug manufacturers have a right to continue to sell drugs free of liability once approval has been given. ${ }^{160}$ However, rejecting impossibility preemption here would not render preemption a "dead letter" 161 because Mutual Pharmaceutical was not legally obligated by New Hampshire's design-defect law to modify its label in a way that federal law prohibits. 162 Under applicable New Hampshire law, an unreasonably dangerous drug manufacturer has several options: "it can change the drug's design or label ... to alter its risk-benefit profile, remove the drug from the market, or pay compensation as a cost of doing business." 163 Therefore, New Hampshire law allowed this manufacturer to either remove Sulindac from the market or pay compensation to the injured party as a result of the injury. 164

New Hampshire's design-defect law did not explicitly require Mutual to change the label for Sulindac and it did not mandate a change to Sulindac's design. 165 Rather, under New Hampshire law, the warning label is one factor in a non-exhaustive list. 166 The applicable New Hampshire law required nothing more than compensating an individual who was determined by a jury to have been injured by an "unreasonably dangerous drug." 167 As the district court made clear, Mutual was held liable for failing to adequately label Sulindac so that it was not "unreasonably dangerous," not for "failing to change" its warning. 168 New Hampshire sought to facilitate federal statutes by providing legal protection to its residents. Providing such legal protection

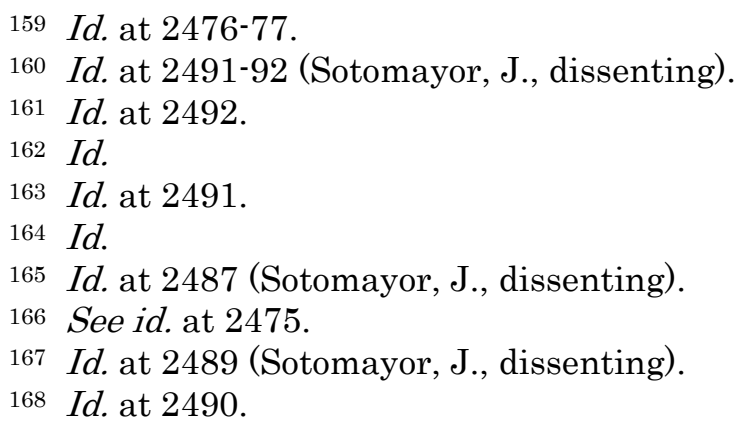


is "a choice that a sovereign State may [and often does] impose to protect its citizens from dangerous drugs or ... ensure that seriously injured consumers receive compensation."169

Manufacturers should have a duty to monitor the safety and efficacy of their products by being required to approach the FDA to propose label changes when necessary. It has remained central to FDCA and FDA regulations that a drug manufacturer bears the responsibility for the content of its label "at all times." 170 Additionally, if Congress thought that state-law causes of action (such as New Hampshire's discussed in Bartlett) posed an obstacle to statutory objectives, it surely would have enacted express preemption provisions at some point during the FDCA's seventy-year history. Congress had the opportunity to explicitly apply the preemption doctrine to pharmaceuticals, yet it declined to do so and only applied it to medical devices. ${ }^{171}$ Congress has never explicitly preempted state law tort claims against drug manufacturers. ${ }^{172}$ While it is possible the Court's "statement that tort remedies and direct regulation do 'the same thing' may fade away when the Court again is presented with the issue and has the opportunity to treat it with more care[,] "173 irreparable harm will likely occur if this issue is not addressed sooner.

\section{B. Indiana's Statutory Analysis and the Importance of State Law}

State tort law causes-of-action provide remedies to individuals harmed by the negligent acts of others. Tort laws play an important role in filling gaps in federal law and in discovering risks and "in providing incentives for manufacturers to remove dangerous products from the market promptly." 174 In holding a particular state law

\footnotetext{
169 Id. at 2491.

170 Wyeth v. Levine, 555 U.S. 555, 570-71 (2009).

171 See Riegel v. Medtronic, Inc., 552 U.S. 312, 340 (2008).

172 PLIVA, Inc. v. Mensing, 131 S.Ct. 2577 (2011).

173 Wolfman \& King, supra note 134.

174 Jocelyn Bogdan, America's Unaccountable Generic Drug
} 
preempted by federal law, injured consumers often have to rely on imperfect federal agencies with limited resources for relief. ${ }^{175}$ Because detrimental effects may occur when federal law preempts state law, Congress takes affirmative steps when it believes tort law may compromise significant federal objectives under a scheme of premarket regulatory review for products it wants to make available. ${ }^{176}$ Federal agencies themselves consider tort litigation supplementary to its agencies regulations and enforcement activities. ${ }^{177}$

Indiana law is similar to New Hampshire law in that it provides residents with state law causes-of-action. ${ }^{178}$ Under design-defect law in Indiana, a product may be defective through manufacturing flaws, defective design, or by a failure to supply complete information about the product's dangers. ${ }^{179}$ To establish a prima facie case of strict liability in Indiana, the plaintiff has the burden of proving each of the following: "(1) the product is defective and unreasonably dangerous, (2) the defective condition existed at the time the product left defendant's control, and (3) the defective condition was the proximate cause of the plaintiff's injuries." 180 A product liability action based on the doctrine of strict liability may not be maintained against a seller

Industry: How Legal Immunity Could be Making You Sick, Center for Justice Democracy (Dec. 2013), http://centerjd.org/content/americasunaccountable-generic-drug-industry.

175 Leslie Pray \& Sally Robinson, Challenges for the FDA: The

FutURE OF DRUG SAFETY (2007), available at
http://www.ncbi.nlm.nih.gov/books/NBK52926/ (According to Mr. Thompson, the FDA has been chronically under-funded in carrying out its responsibilities for ensuring the safety of drugs, medical devices, and the nation's food supply. While the FDA is commonly viewed as the global gold standard for consumer protection, it faces stiff competition for scarce resources and over the past 20 years has been tasked to do far more with its limited resources).

176 Mut. Pharm. Co., Inc. v. Bartlett, 133 S.Ct. 2466, 2496 (2013) (Sotomayor, J., dissenting).

177 Id. at 2485. See also Bates v. Dow Agrosciences LLC, 544 U.S. 431, 451 (2005).

178 See Natural Gas Odorizing, Inc. v. Downs, 685 N.E.2d 155 (Ind. Ct. App. 1997).

179 See Ind. Code $§ 34-20$ et seq. (2015).

180 Natural Gas Odorizing, Inc., 685 N.E.2d at 160. 
unless the seller is a "manufacturer of the product or of the part of the product alleged to be defective." 181

Whether a product is in an unreasonably dangerous and defective condition is a question of fact. ${ }^{182}$ Indiana requires that the plaintiff show that a product is in a "defective condition" and also that it is "unreasonably dangerous." 183 An objective inquiry is required to determine whether a product is defective or unreasonably dangerous. This inquiry focuses on the product and its manufacturer or seller assessed by an objective standard regarding expected use. ${ }^{184}$ The "unreasonably dangerous" requirement "refers to any situation in which the use of a product exposes the user or consumer to a risk of physical harm to an extent beyond that contemplated by the ordinary consumer who purchases the product with the ordinary knowledge about the product's characteristics common to the community of consumers." 185

Even if the seller (manufacturer) has exercised all reasonable care in the preparation and manufacturing of a product, a person selling, leasing, or otherwise putting a defective or unreasonably dangerous product in the stream of commerce is subject to liability. ${ }^{186}$ However actions claiming design-defect require that the "party making the claim must establish that the manufacturer or seller failed to exercise reasonable care under the circumstances in designing the product or in providing the warnings or instructions." 187 For example, in Indiana Ms. Bartlett would have had to establish that Mutual Pharmaceutical failed to exercise reasonable care in providing warnings for their drug Sulindac.

181 Ind. Code $\S 34-20-2-3$ (2015).

182 Corbin v. Coleco Indus., Inc., 748 F.2d 411, 419 (7th Cir. 1984).

183 Bourne v. Marty Gilman, Inc., 452 F.3d 632, 635-36 (7th Cir. 2006) (citing McMahon v. Bunn-O-Matic Corp., 150 F.3d 651, 657 (7th Cir. 1998)). See also Baker v. Heye America, 799 N.E.2d 1135, 1140 (Ind. Ct. App. 2003)).

184 Moss v. Crosman Corp., 945 F.Supp. 1167, 1181 (N.D. Ind. 1996).

185 Ind. Code $\S 34-6-2-146$ (2015).

186 Ind. Code $\S 34-20-2-2$ (2015).

187 Id. 
Under Indiana law a product is not presumed unreasonably dangerous if it injures a person in a way known to the community of persons consuming the product. ${ }^{188}$ This is likely not applicable in pharmaceutical cases because one is unlikely to take a drug if the community of consumers knows of its dangers. The relative obviousness of a defect is relevant in considering whether or not a product is defective and unreasonably dangerous. ${ }^{189}$ The relative obviousness of a defect is unlikely to effect suit against a pharmaceutical manufacturer because consumers will not take drugs that have an obvious defect. Furthermore, obvious defective drugs would not be permitted for sale in the market. Finally, manufacturers are legally bound to design and build products that are reasonably fit and safe for their intended purpose. ${ }^{190}$

Had Bartlett been decided years ago, many past decisions would likely have had different outcomes. Examining the effects of this precedent on previous decisions helps reveal the danger of this precedent to future cases. In Bell v. Lollar, the Indiana Court of Appeals reasoned that a state-law claim against a generic drug manufacturer in a failure-to-warn claim was not preempted because the manufacturer was free to strengthen its label. 191 The plaintiff, Lollar, alleged the label was in a "defective and unreasonably dangerous condition" because the label failed to warn him of the "risk associated with combining acetaminophen and alcohol." 192 The court agreed, holding that the manufacturer "was free to strengthen its label by adding an alcohol warning" and the

188 Moss, 945 F.Supp. at 1176.

189 Johnson v. Kempler Indus., Inc., 677 N.E.2d 531, 538 (Ind. Ct. App. 1997).

190 Liberty Mut. Ins. Co. v. Rich Ladder Co., Inc., 441 N.E.2d 996, 999 (Ind. Ct. App. 1982).

191 Bell v. Lollar, 791 N.E.2d 849, 850 (Ind. Ct. App. 2003).

192 Id. at 851. See also Acetaminophen, DRUGS.COM, www.drugs.com/acetaminophen.html (last visited Mar. 21, 2015) (Acetaminophen is a drug used to reduce fever and relieve pain that is used to treat many conditions, including "headache, muscle aches, arthritis, backache, toothaches, colds, and fevers." It is a common drug and there are many brands and forms available in the marketplace). 
plaintiff's "state law claim for failure to warn [was] not implicitly preempted by the FDCA." 193

If the court in Lollar had used Bartlett as precedent, it is likely Mr. Lollar would not have had a cause of action to supplant his "alcoholic hepatitis, alcoholic dependency continuous, alcoholic gastritis with hemorrhage, and acute renal failure" 194 The decision would be different under Bartlett because a generic drug manufacturer is not able to unilaterally change the drugs label, other than to match the label of a brand-name drug as required under the duty-ofsameness. Like New Hampshire, Indiana as a sovereign state chose to create certain causes-of-action to protect its citizens rights. The underlying purpose of Indiana's (and New Hampshire's) causes-of-action is not to force companies to change their labels, but to compensate the injured and to punish the negligent. This rationale was pointed out by the dissent in Mutual which stated that the manufacturer was held liable for breaching the duty to adequately label Sulindac so that it was not "unreasonably dangerous," not for "failing to change" its warning. ${ }^{195}$

In the similarly decided Indiana case, Tucker $v$. SmithKline Beecham Corp., the plaintiff brought a wrongful death claim under Indiana law against the defendant drug manufacturer, claiming that her brother committed suicide as a result of taking the manufacturer's antidepressant and that the drug manufacturer breached its duty to warn. 196 The court held that there was no preemption by reasoning that the manufacturer had a duty to strengthen its label and that "if the FDA exercise[d] its power to disapprove the revised label, the FDA's disapproval is not retroactively illegal; the manufacturer [can] simply stop[] distributing the new label." 197 Thus, under the court's holding, the deceased

193 Bell, 791 N.E.2d at 855.

194 Id. at 850.

195 Mut. Pharm. Co., Inc. v. Bartlett, 133 S.Ct 2466, 2490 (2013) (Sotomayor, J., dissenting).

196 Tucker v. SmithKline Beecham Corp., 596 F.Supp.2d 1225, 1227 (S.D. Ind. 2008).

197 Id. at 1229 (citing 21 C.F.R. $\S 314.70($ c); Witczak v. Pfizer, Inc., 377 F.Supp.2d 726, 729 (D. Minn. 2005)). 
beneficiary/next-of-kin would have a cause-of-action because the manufacturer failed in its duty to provide a label that is not "unreasonably dangerous."

The Tucker decision likely would have been decided differently if the court had relied upon Bartlett as precedent. If the Tucker court relied on Bartlett, the court likely would have concluded that the preemption doctrine would apply because it would be impossible for the drug manufacturer to comply with the state law of strengthening the drug's label so as to not make it unreasonably dangerous and with the federal law requiring the same label as the brand-name counterpart. An inequitable decision would have resulted, as a negligent drug manufacturer would have left the injured party's beneficiary/next-of-kin without legal recourse to address the manufacturer's negligence.

Following the decisions in PLIVA and Bartlett, as many as $6,596,855$ Indiana residents may be left without legal recourse to address generic drug manufacturer breaches. ${ }^{198}$ These two decisions are in essence providing legal immunity to generic drug manufacturers. Approximately $80 \%$ of all drugs purchased are generic. Therefore, as many as $3,694,239$ Indiana residents may be left without the right to sue generic drug manufacturers. ${ }^{199}$ It remains important to address this large legal gap.

\section{Recourse Available to Generic Drug Consumers}

Today, seven in ten Americans take prescription drugs to treat various health issues. ${ }^{200}$ A significant portion of these

198 Indiana, U.S. CENSUS BUREAU, available at http://quickfacts.census.gov/qfd/states/18000.html (last visited Mar. 30, 2015).

199 Id. See also Footnote 1. Because approximately 7 in 10 Americans have taken prescription drugs, an estimated 4,617,798 Indiana residents have taken prescription drugs. Because $80 \%$ of drugs taken are generic, an estimated 3,694,239 Indiana residents have taken generic prescription drugs $(6,596,855$ residents divided by $70 \%$ (the percentage of individuals taking prescription drugs) divided by $80 \%$ (the estimated number of individuals that take generic drugs)).

200 Nearly 7 in 10 Americans, supra note 4. 
individuals who opt to take generics will have no access to compensation if injured as a result of a drug manufacturer's design-defect or failure-to-warn. Many consumers are not aware of this legal loophole and those that are face a very difficult situation: should they purchase the more expensive brand-name drugs that provide legal protection or should they purchase the more affordable generic equivalent without such protection? This assumes consumers have the ability to purchase more expensive brand-name drugs, when in fact many are unable to do so. Furthermore, many prescriptions are unknowingly filled by generic equivalents at pharmacies.

Legal scholars have discussed creative arguments to avoid this preemption barrier. One strategy to avoid being preempted is to file a "failure to update" claim accusing generic manufacturers of not changing labels quickly enough after the brand-name equivalent updated their label.201 This claim would only be plausible if the brandname manufacturer had already discovered this issue and had changed the drugs label.

Assuming the brand-name drug manufacturer has not discovered the issue, four potential course of action remain. First, one could sue the brand-name manufacturer alleging they bear responsibility for the generic drug's shortcomings. Second, one could sue the generic drug manufacturer under the FDCA's misbranding statute. Third, one could opt to purchase brand-name drugs and not their generic counterparts. The final and most complete solution would be to petition Congress and the FDA to take action to correct this dangerous precedent.

\section{Option One - Suing the Name Brand Manufacturer}

The first option available to consumers injured by generic drugs would be to sue the brand-name equivalent manufacturer. Under this cause of action that is often

201 Lorelei Laird, Generic Drugs Leave a Bad Taste for Patients Filing Tort Suits, ABA J. (Feb. 1, 2014, 9:20 AM), http://www.abajournal.com/mobile/mag_article/generic_drugs_leave_a_b ad_taste_for_patients_filing_tort_suits. 
referred to as "innovator liability," injured drug consumers could file suit against brand-name manufacturers claiming that they bear sole responsibility for a generic manufacturer's label. ${ }^{202}$ As it currently stands, "PLIVA and Mutual may provide complete (or at least substantial) immunity to generic manufacturers, but their reasoning - that generic drug labels are the province of brand-name manufacturers - - is consistent with a state-law duty that makes brand-name manufacturers responsible." 203 Thus, these brand-name suits would be based on claims of "negligent and/or intentional misrepresentation, which plaintiffs [could argue] . . a authorizes liability against a non-seller who has reason to know that a third party could suffer harm." 204 Many states, including Indiana, do recognize liability for negligent misrepresentation. 205 However, no Indiana precedent has been established on this issue and many states have held that brand-name suits are

202 See Fullington v. Pfizer, Inc., 720 F.3d 739, 747-48 (8th Cir. 2013) (Murphy, J., concurring) (explaining in dicta that PLIVA and Bartlett "severely eroded the foundation of th[e] analysis" of the courts that have rejected brand-name suits because that analysis has "generally been predicated on the assumption that the generic manufacturers could independently safeguard and strengthen their own labels").

203 Wolfman \& King, supra note 134.

204 Id. (citing Conte v. Wyeth, Inc., 85 Cal. Rptr. 3d 299, 309-10 (Cal. Ct. App. 2008) (explaining differences in strict products liability and misrepresentation theories in case brought by generic drug user who sued brand-name manufacturer on misrepresentation theory)). See also Restatement (SECOND) OF TORTS $§ 311$ (1965) ("One who negligently gives false information to another is subject to liability for physical harm caused by action taken by the other in reasonable reliance upon such information, where such harm results . . . to such third persons as the actor should expect to be put in peril by the action taken.").

205 See Passmore v. Multi-Mgmt. Servs., Inc., 810 N.E.2d 1022, 1025 (Ind. 2004). See also Kimball Parker, A Historical Approach to Negligent Misrepresentation and Federal Rule of Civil Procedure 9(b), 80 U. CHI. L. REV. 1461 (2013) (discussing different circuits interpretations and treatments of negligent misrepresentation claims). 
not viable under state law due to their stretched foreseeability concept. ${ }^{206}$

The Alabama Supreme Court established precedent on the above theory in Wyeth, Inc. v. Weeks by holding that their law permits brand-name drug manufacturers to be held liable for misrepresentations, even if a generic equivalent drug was taken. 207 The court addressed the unfairness argument by stating that "alleged misrepresentations were drafted by the brand-name manufacturer and merely repeated . . . by the generic manufacturer." 208 The court reasoned that the special sameness requirement gave them the ability to consider the innovator liability argument. 209 The court cited to the unique relationship between the brand-name and generic drugs. ${ }^{210}$

The Alabama Supreme Court reheard the case in September 2013. ${ }^{211}$ After rehearing, the Alabama Supreme Court affirmed their previous ruling in a 6-3 decision. Many argued against this decision claiming it is "a basic of products liability, it's in the Restatement of Torts ... that a manufacturer is responsible [only] for the products it makes . . . ."212 Unfortunately, there are several cases in their favor; as of January 2014, "77 cases [said] name-brand manufacturers don't owe any duty to people who never took their products [and] [s] ix federal appeals courts have ruled that way." 213 The Supreme Court of Iowa recently rejected this innovator liability theory in the decision Huck $v$. Wyeth. ${ }^{214}$

206 See Foster v. Am. Home Prods. Corp., 29 F.3d 165 (4th Cir. 1994); Baymiller v. Ranbaxy Pharm., Inc., 894 F.Supp.2d 1302 (D. Nev. 2012) (holding that Consumer's use of generic pharmaceutical precluded claims of strict products liability against brand-name manufacturer).

207 Wyeth, Inc. v. Weeks, 1101397, 2014 WL 4055813 (Ala. Aug. 15, 2014).

$208 I d$. at $* 23$.

209 Id.

$210 I d$.

211 Id.

212 Laird, supra note 201.

213 Id.

214 Huck v. Wyeth, Inc., 850 N.W.2d 353 (Iowa 2014). 
An innovator liability cause of action would be based on negligent and/or intentional misrepresentation and not on strict product liability. The negligent and/or intentional misrepresentation suit would "authorize[] liability against a non-seller who has reason to know that a third party could suffer harm." 215 Thus, the injured party could allege that even if a generic equivalent drug was taken, the brandname manufacturer's label error was a foreseeable cause of his/her injuries because the generic drug manufacturer should reasonably know that "whenever one of its products is mislabeled, the generic product will be as well."216 Most courts have dismissed these types of "innovator liability claims" by reasoning that plaintiffs should not be able to sue drug manufacturers that did not make the drug they consumed. 217

\section{Option Two - Suing the Generic Drug Manufacturer for Misbranding}

An individual injured from a generic drug could bring suit against the generic drug manufacturer under the FDCA's misbranding statute. ${ }^{218}$ This misbranding statute provides that a drug is misbranded if, amongst other things, "[i]t is dangerous to health when used in the dosage or manner, or with the frequency or duration prescribed, recommended, or suggested in the labeling . . . ." 219 Mutual's majority reasoned that "[f]ederal law itself bars the sale of previously approved drugs if new information comes to light demonstrating that the drug is 'dangerous to health' and thus 'misbranded." 220 However, following the PLIVA decision, a misbrand-based claim would probably

215 Wolfman \& King, supra note 134.

216 Id.

217 Lorelei, supra note 201.

218 See 21 U.S.C. $\S 352$ (2015).

219 Labeling Requirements - Misbranding, U.S. FoOD \& DRUG ADMIN., http://www.fda.gov/MedicalDevices/ DeviceRegulationandGuidance/Overview/DeviceLabeling/GeneralDevice LabelingRequirements/ucm052190.htm (last updated Mar. 11, 2015).

220 Mut. Pharm. Co., Inc. v. Bartlett 133 S.Ct. 2466, 2492 (2013) (citing 21 U.S.C. $\S \S 331(a), 352(\mathrm{j})$ (2015)). 
need to be brought as a design-defect claim. Although unlikely to succeed, this type of lawsuit does remain available.

\section{Option Three - Paying for Protection Through Brand Name Drugs}

Individuals seeking to avoid injury without recourse may purchase brand-name drugs as opposed to their generic equivalents. The cost difference is often substantial and consumers will have to decide if the average $\$ 100$ price difference is worth the risk. ${ }^{221}$ Having this option as a solution is not sufficient to protect the estimate 1,015,916 Indiana residents living under the poverty rate. ${ }^{222}$ Furthermore, some health insurance providers will not pay for brand-name drugs if a generic equivalent is available. ${ }^{223}$ Therefore, this option would only help certain individuals that know of this legal issue and are able and willing to purchase brand-name drugs.

221 See Generic Versus Brand Medications, HeAlthSmaRT, http://www.healthsmart.com/SmarterHealth/GenericvsBrandDrugs.asp $\mathrm{x}$ (last visited Mar. 21, 2015) (noting that in 2008 the average price of a brand-name drug was $\$ 137.90$, while their generic counterparts were only $\$ 35.22$ ).

222 Indiana, U.S. CENsus BuREAU, available at http://quickfacts.census.gov/qfd/states/18000.html (last visited Mar. 30, 2015) $(6,596,855 \times .154$ - persons below the poverty level from 2009-2013 averaged $15.4 \%$. For purposes of this example I have assumed the poverty level would remain $15.4 \%$ in 2014)).

223 See Michael Bihari, Understanding Your Health Plan, ABOUT.COM

http://healthinsurance.about.com/od/prescriptiondrugs/a/understanding formulary.htm (last visited Mar. 21, 2015) (Drugs are often grouped into tiers and "[t]ier 1 has the lowest co-payment and usually includes generic medications." "Tier 2 has a higher co-payment than tier 1 and usually includes preferred brand-name medications." Finally, "[t]ier 3 has the highest co-payment and usually includes non-preferred brandname medications."). 


\section{Option Four - Legislative Amendment}

Attorneys are capable of crafting creative arguments and some consumers are capable of purchasing brand-name drugs as opposed to their generic equivalents. However, both of these options fail to address the issue at hand which is the dangerous legal precedent established by the Court. The only complete solution to this legal dilemma is to amend the labeling requirements and duties of all drug manufacturers. Furthermore, Congress could solve the issue of preemption by explicitly saying preemption is not present and that a state law provides recourse to individuals injured by generic drugs. One could argue that the FDA may have authority to solve such an issue, but to avoid future lapse of legal recourse ${ }^{224}$ it would best to statutorily amend the law.

By amending the Hatch-Waxman Act, Congress could hold generic manufacturers liable for failing-to-warn or failing-to-update their labels, which would invariably allow injured consumers legal recourse. Currently, unilateral changes by generic drug manufacturers are not permitted because generic drug manufacturers must abide to a duty of sameness. ${ }^{225}$ Modifying the appropriate provision to allow and even require generic drug manufacturers to update their labels would properly shift the burden onto the manufacturer and it would permit consumers legal recourse if these manufacturers failed in this duty.

Another possible solution available to Congress would be to "provide that generic drug manufacturers . . . are authorized to use the CBE process." 226 Currently, CBE

224 See Wyeth v. Levine, 555 U.S. 555, 567 (2009) (The FDA may not have the authority to modify the "sameness" requirement to allow generic drug manufacturers to be liable for design-defect claims. Indeed, prior to 2007, the FDA lacked the authority to order manufacturers to revise their label and only when Congress granted the FDA this authority did the agency have the ability to modify the rule); Louisiana Pub. Serv. Com'n v. F.C.C., 476 U.S. 355, 374 (1986) (“[A] federal agency may pre-empt state law only when and if it is acting within the scope of its congressionally delegated authority.").

225 See generally 21 C.F.R. $§ 314.150$ (2015).

226 Wolfman \& King, supra note 134. 
rules allowing non-generic drug manufacturers to unilaterally change and strengthen their labels are unavailable to ANDA holders. Because generic drugs have taken the majority of the pharmaceutical market share, these manufacturers are in a better position to collect and report data. This amendment would be especially important for the one-third market-share that has no brand-name counterpart on the market at all. 227 By modifying the CBE statute, generic drug manufacturers would be required to unilaterally strengthen their warnings without having to comply with the sameness requirements. Legislation was previously introduced into the Senate and House of Representatives in 2012 to give ANDA holders the ability to change labeling but the bill never reached the floor. ${ }^{228}$

Following the Bartlett decision and public outcry, the FDA acknowledged it "is considering a regulatory change that would allow generic manufacturers, like brand-name manufacturers, to change their labeling in appropriate circumstances," adding that "if such a regulatory change is adopted, it could eliminate failure-to-warn preemption claims against generic-drug manufacturers." ${ }^{229}$ The FDA has announced that they are working on label requirement modification requirements; the FDA's Notice of Proposed Rulemaking entitled "Supplemental Applications Proposing Labeling Changes for Approved Drugs and Biological Products" has been identified as seeking to "revise and clarify procedures for application holders of an approved drug or biological product to change the product labeling to reflect certain types of newly acquired information in

227 Transcript of Oral Argument at 41, PLIVA, Inc. v. Mensing, 131 S.Ct. $2567 \quad$ (2011) (No. 09-993), available at http://www.supremecourt.gov/oral_arguments/argument_transcripts/09993.pdf.

228 See Patient Safety and Generic Labeling Improvement Act, S. 2295, 112th Cong. (2012); Patient Safety and Drug Labeling Improvement Act, H.R. 4384, 112th Cong. (2012).

229 Wolfman \& King, supra note 134. 
advance of FDA's review of the change." 230 According to the FDA, this proposed provision would create "parity" between NDA and ANDA holders with respect to CBE's. ${ }^{231}$ Again, while it would likely face opposition ${ }^{232}$ the ultimate goal of the FDA should be to foster public safety. Such an amendment would help achieve this goal.

The FDA has acknowledged difficulty in handling the growing pharmaceutical industry. It is likely this issue will continue to worsen as the medical industry becomes more complex and as drug sales continue to grow. Tort laws play an important role in supplementing the FDA because the FDA neither provide remedies nor compensates victims for their injuries. Furthermore, tort laws play a crucial role in ensuring safety compliance within the pharmaceutical industry. While reducing tort liability for generic manufacturers may eventually result in more affordable

230 Leslie Kux, Supplemental Applications Proposing Labeling Changes for Approved Drugs and Biological Products, FED. REg. (Nov. 5, 2013), https://www.federalregister.gov/articles/2013/11/13/201326799/supplemental-applications-proposing-labeling-changes-forapproved-drugs-and-biological-products.

231 Id.

232 See Rich Samp, Can FDA Lawfully Overrule SCOTUS Generic Drug Preemption Decision Through Regulation?, ForBes (Aug. 2, 2013, 10:17 AM), http://www.forbes.com/sites/wlf/2013/08/02/can-fda-lawfullyoverrule-scotus-generic-drug-preemption-decision-through-regulation/2/ (Opponents could argue that it makes little sense to hold generic drug manufacturers, who are by definition relying on others' safety data in marking their products, to make unilateral determinations that the FDA's judgments regarding proper labeling should be overridden. It is also likely that generic drug manufacturers will seek to influence such a law, as its passing would likely hold them more accountable and likely to be sued.). See also Wyeth v. Levine, 555 U.S. 555, 582 (2009) (Breyer, J., concurring) ("I also note that some have argued that state tort law can sometimes raise prices to the point where those who are sick are unable to obtain the drugs they need.")); Travis Sales et al., FDA and Potential New Rules for Labeling of Generic Drugs, PHARMACEUTICAL COMPLIANCE MONITOR (October 7, 2013), http://www.pharmacompliancemonitor.com/fda-and-potential-new-rulesfor-labeling-of-generic-drugs/5664/\#_edn2 (opponents may argue that the sameness requirement is important to "minimize any confusion among healthcare professionals and consumers as well as to preclude a basis for lack of confidence in the equivalency of generic versus brandname products"). 
drugs, the consequences of legal immunity and public safety outweigh this position. As summarized by the Court in Wyeth, "[s] tate tort suits uncover unknown drug hazards and provide incentives for drug manufacturers to disclose safety risks promptly." 233

\section{CONCLUSION}

Congress should, and indeed must act to protect its constituents from the legal loophole resulting from the Court's two recent decisions in PLIVA and Bartlett. Consumers should not face the decision of choosing between legal protection and essential living supplies. Attorneys are able to craft creative legal arguments, but at the expense of clients and their own peril. The only true solution to the loophole is legislative reform. Without such action, generic drug manufacturers will remain free from liability and many injured generic-drug consumers will remain without any legal remedies. 